\title{
Influence of soaking temperature time on the ability prepared liquefaction of wood from cashew nut shell waste
}

\author{
Do Quang Minh ${ }^{1,2}$, Huynh Ngoc Minh ${ }^{1,2}$, Nguyen Vu Uyen Nhi ${ }^{1,2}$, Kieu Do Trung Kien ${ }^{1,2, *}$
}

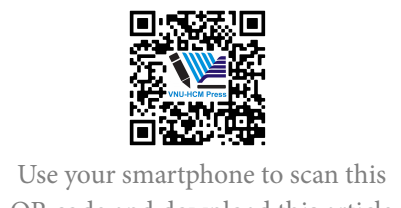

QR code and download this article

${ }^{1}$ Department of Silicate Materials,

Faculty of Materials Technology, Ho Chi Minh City University of Technology

(HCMUT), 268 Ly Thuong Kiet Street,

District 10, Ho Chi Minh City, Vietnam

${ }^{2}$ Vietnam National University Ho Chi Minh City, Linh Trung Ward, Thu Duc District, Ho Chi Minh City, Vietnam

\section{Correspondence}

Kieu Do Trung Kien, Department of Silicate Materials, Faculty of Materials Technology, Ho Chi Minh City University of Technology (HCMUT), 268 Ly Thuong Kiet Street, District 10, Ho Chi Minh City, Vietnam

Vietnam National University Ho Chi Minh City, Linh Trung Ward, Thu Duc District, Ho Chi Minh City, Vietnam

Email: kieudotrungkien@hcmut.edu.vn

History

- Received: 25-11-2020

- Accepted: 16-03-2021

- Published: 30-03-2021

DOI : 10.32508/stdjet.v4i1.796

\section{Check for updates}

\section{Copyright}

(๑) VNU-HCM Press. This is an openaccess article distributed under the terms of the Creative Commons Attribution 4.0 International license.

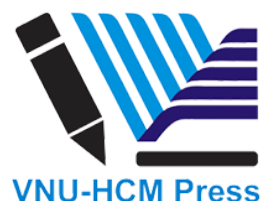

\section{ABSTRACT}

Liquefied wood is one of the phenolic resin. However, unlike commercial phenolic resins that are normally synthesized by the chemical reaction between phenol and formaldehyde, liquefied wood is usually produced by reacting phenol with wood-derived materials, and catalyst at $120-180^{\circ} \mathrm{C}$. Depending on whether the catalyst is a base or a acid, the formed resin is a thermoset or a thermoplastic. In this study, wood liquefaction was prepared from a cashew nut shell waste (CNSW), phenol, and sulfuric acid catalyst. The cashew nut shell waste is taken from Binh Phuoc province Vietnam and crushed to a size of less than $500 \mu \mathrm{m}$. Phenol and sulfuric acid catalyst are chemical experiments. The powder of cashew nut shell waste, phenol, and sulfuric acid were mixed and reacted at $150^{\circ} \mathrm{C}$ for different soaking times. An optimal soaking temperature time was determined through a cashew nut shell waste residue content in wood liquefaction products. The wood liquefaction products also were determined by a number average molecular weight $\left(M_{n}\right)$ and a weight average molecular weight $\left(M_{w}\right)$ by Gel permeation chromatography method (GPC); the function groups by Fourier Transform Infrared method (FT-IR). The results showed that the formed resin is thermoplastic and the optimal soaking time to prepared liquefied wood is 180 minutes. This sample has a residual cashew nut shell waste ratio of $9.44 \%$, a number average molecular weight of 7552, and a weight average molecular weight of 10640. The liquefied wood from cashew nut shell waste can be used as a binder in the manufacture of the medium density fiberboard (MDF) or as a material to promote the sintered process in the production of woodceramic materials. In addition, the liquefied wood can also be pyrolyzed to form carbon fiber. Carbon fiber can be applied as reinforcing materials for ceramic products.

Key words: phenolic resin, liquefied wood, cashew nut shell waste

\section{INTRODUCTION}

Phenolic resin is a resin synthesized from the phenol and formaldehyde. It was commercialized and was put into industrial production in the early 20th century. Phenolic resin has good thermal stability, capable of binding and high carbon content. When decomposed at high temperatures, the phenolic resin can transform into carbon fiber structures ${ }^{1}$. Carbon fiber can be applied as reinforcement materials ${ }^{1,2}$.

There are many methods for synthetic phenolic resin. Liquefied wood is one of the methods that have been studied $^{3}$. By this method, the wood will be transformed into a high-molecular material with a strong odor and dark black color by giving the phenol or multi-functional alcohol to react with a catalyst. This transformed process is complicated and has many products to form.

There have been many studies to fabricate wood liquefaction such as: using wood to react with polyethylene glycol/ glycerol/ polyhydric alcohol, and catalytic sulfuric acid at $150^{\circ} \mathrm{C}$ to create wood liquefaction ${ }^{4-6}$. In addition, ethylene glycol, sulfuric acid, and wood are also combined to make wood liquefaction ${ }^{7-9}$. Several studies have also used phenol and acid catalysts such as sulfuric acid, phosphoric acid to make wood liquefaction from the wood pulp at $120-180^{\circ} \mathrm{C}^{10,11}$. Regarding wood materials for fabricating wood liquefaction, studies often use agricultural waste to fabricate wood liquefaction. Types of agricultural waste can be mentioned as the fruit of oil palm ${ }^{12}$, the wood of Japanese cedar ${ }^{13}$, waste paper ${ }^{14}$, bagasse ${ }^{15}$, corn stover $^{16}$.

It can be seen that these research directions consider wood liquefaction made from wood-based raw materials as renewable resources to replace fossiloriginated plastic. It contributes to addressing concerns about fossil fuel exhaustion issues and environmental pollution. In agriculturally developed countries like Vietnam, this research direction is even more important in the use of industrial waste products to make wood liquefaction into a product of economic value. 
In Vietnam, cashew is one of the important industrial trees. Due to exporting cashew nuts only, cashew nut shell has become one of the waste items in the cashew industry. Cashew nut shell is often pressed to get cashew oil. However, the cashew nut shell after pressing (often called the cashew nut shell waste) is still a waste to be treated. There have been some studies using cashew shell waste to fabricate ceramic ${ }^{17,18}$. Other studies have also used cashew shell waste to make wood liquefaction ${ }^{19,20}$. This research will study the influence of soaking temperature time on the ability to prepared wood liquefaction from cashew nut shell waste.

\section{EXPERIMENTAL METHODS}

\section{Raw materials}

CNSW was taken from Binh Phuoc. Chemical composition was shown in Table 1 and Table 2. CNSW was washed and crushed to a size of less than 500 $\mu \mathrm{m}$. Phenol (1.07 $\mathrm{g} / \mathrm{cm}^{3}$, Merck) and $98 \%$ sulfuric acid $\left(1.84 \mathrm{~g} / \mathrm{cm}^{3}\right.$, Merck) were also used to fabricate wood liquefaction from CNSW.

Phenol, CNSW were mixed with the ratio of $2 / 1$ (wt.) and 5\% sulfuric acid According to the amount of phenol used. The mixed mixtures were placed in the drying oven and soaked at $150{ }^{\circ} \mathrm{C}$ for different time periods to make wood liquefaction. The soaking temperature times are shown in Table 3.

Optimum soaking time was determined by analyzing properties such as vibrational units of functional groups by FT-IR method; Wood liquefaction reaction efficiency through assessment of residual CNSW ratio; The number average molecular weight $\left(M_{n}\right)$ and the weight average molecular weight $\left(\mathrm{M}_{w}\right)$ by Gel chromatography (GPC) method.

\section{Methods}

Fourier-transform infrared spectroscopy (FTIR):

The vibration of the functional groups of wood liquefaction was analyzed by Fourier-transform infrared spectroscopy (FT-IR - Model Nicolet 6700, Thermo, USA). The scanning step was 0.9642 with a scanning angle of 500 to $4000 \mathrm{~cm}^{-1}$. The binder was $\mathrm{KBr}$. The test method was a transmittance spectrum.

\section{Determine a residual CNSW:}

Phenolic resin is crushed, filtered, and washed to remove residual phenol in the resin. The washed resin is dried at $70^{\circ} \mathrm{C}$. The sample was then weighed 2,00 \pm 0.01 gram, contained in Erlen, added about $40 \mathrm{ml}$ of ethanol, and swirled well. The sample is filtered slowly through the filter paper and weighed to determine the mass of the filtered sample. After filtration is complete, the filter paper containing the residue is placed in a drying cup and dried to constant weight. The residual CNSW is determined from the following formula:

$$
\% m_{g d}=\frac{m_{s}-m_{g l}}{m_{o}}
$$

$\mathrm{m}_{g d}$ - the percentage of residual CNSW (\%)

$\mathrm{m}_{s}$ - the weight of filter paper and insoluble residue (gram)

$\mathrm{m}_{g l}$ - the weight of dry filter paper (gram)

$\mathrm{m}_{o}$ - the weight of the original phenolic resin (gram)

\section{Gel permeation chromatography (GPC):}

The number average molecular weight $\left(\mathrm{M}_{n}\right)$ and the weight average molecular weight $\left(\mathrm{M}_{w}\right)$ were determined by Gel permeation chromatography method (GPC - Model PL-GPC 50, POLYMERLAB, USA). The used soluble solvent is Dimethyl - Formamide (DMF). The wood liquefaction samples were dissolved in DMF solvent at a concentration of 0.10 $\mathrm{mg} / \mathrm{ml}$. The dosage for each sample injection was $50 \mu 1$.

\section{THE RESULTS AND DISCUSSIONS}

\section{Vibrational units of functional groups by} FT-IR spectrum

Wood liquefaction samples at different soaking times were determined functional groups by FT-IR method. FT-IR spectrums of samples were presented in Figure 1. FT-IR spectrum showed that the samples all had functional groups such as: $\mathrm{CH}_{n}(2929,2850$ $\left.\mathrm{cm}^{-1}\right), \mathrm{C}=\mathrm{O}\left(1700 \mathrm{~cm}^{-1}\right), \mathrm{C}=\mathrm{C}\left(1598 \mathrm{~cm}^{-1}\right), \mathrm{C}-\mathrm{C}$ $\left(1513 \mathrm{~cm}^{-1}\right), \mathrm{CH}_{2}\left(1452 \mathrm{~cm}^{-1}\right), \mathrm{CH}\left(1371 \mathrm{~cm}^{-1}\right)$, OH $\left(1257 \mathrm{~cm}^{-1}\right), \mathrm{C}-\mathrm{H}\left(1092,815,754 \mathrm{~cm}^{-1}\right)(\mathrm{Ta}-$ ble 4$)^{2,3,21,22}$.

The results of the FTIR spectrum of the samples were similar. Comparison with the FTIR spectrum of previous studies showed that there was wood liquefaction formation in all samples ${ }^{2,3,21,22}$. In this case, it is difficult to estimate the optimal retention time for wood liquefaction generation at $150^{\circ} \mathrm{C}$. Therefore, the determination of residual CNSW and the GPC method was used to evaluate this factor.

\section{Determine residual CNSW}

Results from the graph in Figure 2 showed that the residual CNSW of liquefied wood decreased as the soaking time increases. When the retention time increased, the reaction time for creating wood liquefaction was prolonged, the reaction performance also increased. The residue of CNSW was reduced rapidly 
Table 1: The composition of the chemical elements (\% wt.) of CNSW ${ }^{20}$

\begin{tabular}{llllll}
\hline Sample & $\mathrm{C}$ & $\mathrm{N}$ & $\mathrm{H}$ & $\mathrm{O}$ & Others \\
$\mathrm{CSNW}$ & 53.6 & 9.5 & 8.8 & 26.8 & 1.2 \\
\hline
\end{tabular}

Table 2: The composition of chemical compounds (\% wt.) of CNSW

\begin{tabular}{llllllll}
\hline Sample & Cellulose & $\begin{array}{l}\text { Hemi } \\
\text { cellulose }\end{array}$ & Lignin & $\begin{array}{l}\text { Anacardic } \\
\text { acid }\end{array}$ & Cardanol & Cardol & $\begin{array}{l}\text { 2-Methyl } \\
\text { Cardol }\end{array}$ \\
CSNW & $53-56$ & $11-12$ & $16-17$ & $10-15$ & $1-2$ & $2-4$ & $<1$ \\
\hline
\end{tabular}

\begin{tabular}{|c|c|c|c|c|c|}
\hline \multirow[t]{2}{*}{ Sample } & \multicolumn{3}{|c|}{ Ratio (wt.) } & \multirow{2}{*}{$\begin{array}{l}\text { Temperature } \\
\left({ }^{o} \mathrm{C}\right)\end{array}$} & \multirow{2}{*}{$\begin{array}{l}\text { Soaking time } \\
\text { (minutes) }\end{array}$} \\
\hline & Phenol & CNSW & Sulfuric acid $\left({ }^{\star}\right)$ & & \\
\hline ST90 & 2 & 1 & $5 \%$ & 150 & 90 \\
\hline ST120 & 2 & 1 & & 150 & 120 \\
\hline ST150 & 2 & 1 & & 150 & 150 \\
\hline ST180 & 2 & 1 & & 150 & 180 \\
\hline ST210 & 2 & 1 & & 150 & 210 \\
\hline
\end{tabular}

* According to the amount of phenol used

Table 4: Vibration of functional groups

\begin{tabular}{ll}
\hline Wavenumbers $\left(\mathrm{cm}^{-1}\right)$ & Function groups \\
3351 & Vibrate of $\mathrm{OH}$ group of phenolic and methylol \\
2929,2850 & Vibrate of $\mathrm{CH}$ group of aliphatic \\
1700 & Vibrate of $\mathrm{C}=\mathrm{O}$ group of carboxylic \\
1598 & Vibrate of $\mathrm{C}=\mathrm{C}$ group of benzen \\
1513 & Vibrate of $\mathrm{C}-\mathrm{C}$ in aromatic ring \\
1452 & Vibrate of $-\mathrm{CH}$ group \\
1371 & Vibrate of $-\mathrm{CH}$ group \\
1257 & Vibrate of $\mathrm{OH}$ group \\
1092 & Vibrate of C-H group inside the aromatic ring \\
815 & Vibrate of C-H group of benzen \\
754 & Vibrate of C-H group outside the aromatic plane \\
\hline
\end{tabular}

when extending the retention time from 90 to 180 minutes corresponding to the model ST90 to ST180 (from $29.68 \%$ to $9.44 \%$ ). If the soaking time was prolonged, the residue of CNSW would be difficult to reduce further (from $9.44 \%$ to $9.02 \%$ ).

When the heat retention time was prolonged, the chemical reactions between phenol, CNSW, and the acid catalyst would take place more thoroughly. As a result of this process, the amount of CNSW involved in the reaction to create the resin was more, the amount of CNSW remaining after the reaction also was less. However, besides the resin-forming reaction, there was also the thermal decomposition of CNSW $^{23}$. Therefore, when the heat retention time was longer than 180 minutes, the result of CNSW residue decreases very little. The CNSW residue result showed that at $150^{\circ} \mathrm{C}$ the optimal soaking time was 180 minutes.

\section{Determine $\mathbf{M}_{n}$ and $\mathbf{M}_{w}$ by GPC}

The results of the GPC analysis of the samples were presented in Table 5 and Figure 3. According to the 


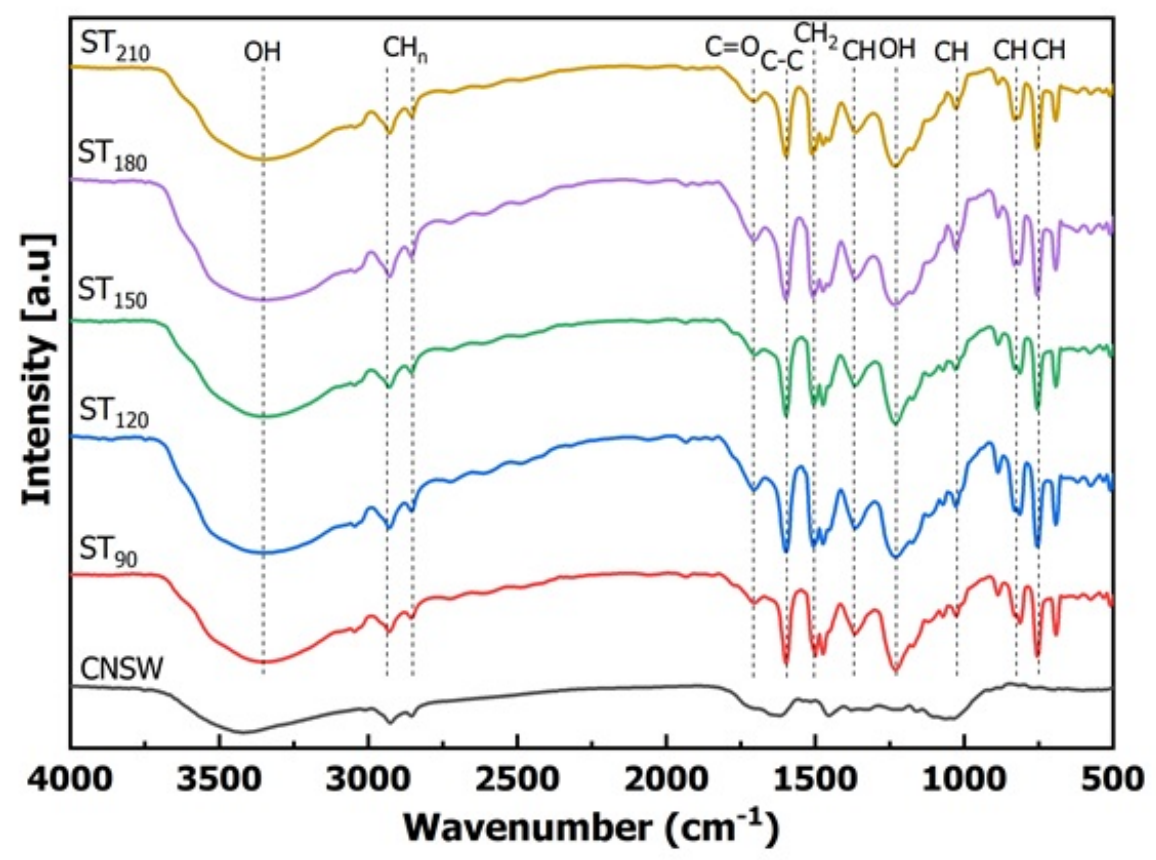

Figure 1: FTIR ofwood liquefaction at $150^{\circ} \mathrm{C}$ for different soaking time

Table 5: Effect of soaking time to residual CNSW ratio

\begin{tabular}{llll}
\hline Sample & Temperature $\left({ }^{\circ} \mathrm{C}\right)$ & Soaking time (minute) & Residual CNSW ratio (\% .wt) \\
ST90 & 150 & 90 & $29.68 \pm 1.45$ \\
ST120 & 150 & 120 & $15.25 \pm 1.36$ \\
ST150 & 150 & 150 & $11.95 \pm 0.91$ \\
ST180 & 150 & 180 & $9.44 \pm 1.15$ \\
ST210 & 150 & 210 & $9.02 \pm 1.24$ \\
\hline
\end{tabular}

data in Table 5 and Figure 3, the samples all had the presence of two characteristic distribution areas. The first region (region 1) had the number average molecular weight $\left(\mathrm{M}_{n}\right)$ in the range of 6997 - 7552 and the weight average molecular weight $\left(\mathrm{M}_{w}\right)$ in the range 10152 - 10849. The second region (region 2) had $\mathrm{M}_{n}$ index in the range $1275-1325$ and $\mathrm{M}_{w}$ in the range of $1545-1755$. This region was the distribution of oligomers.

Kensuke Naka pointed out that polymer had a molecular weight of more than ten thousand and oligomer had a molecular weight of several thousand or less ${ }^{23}$. GPC results showed that region 1 with $\mathrm{M}_{w}$ value over 10000 was the distribution region of the polymer and region 2 with $\mathrm{M}_{w}$ value from 1545 to 1755 was the distribution region of the oligomer. The $\mathrm{W}_{n}$ was used to determine the formation of the liquefied wood at different thermal retention time. When holding the heat at $150^{\circ} \mathrm{C}$ from 90 minutes to 180 minutes (ST90 - ST180 samples), the oligomers linked together to form polymers. The $\mathrm{W}_{n}$ value of the polymer region would increase and the oligomer region would decrease. Conversely, if the holding time was too long (ST210 sample), the $\mathrm{W}_{n}$ value of the polymer region would decrease and the oligomer region would increase. This result demonstrated that prolonging the soaking time also would sever the molecular circuit of the newly formed polymer.

This result combined with the residual CNSW ratio (Figure 1) and the relative intensity ratio of the peaks on the FT-IR spectra (Figure 2) showed that the formed wood liquefaction at different soaking times 


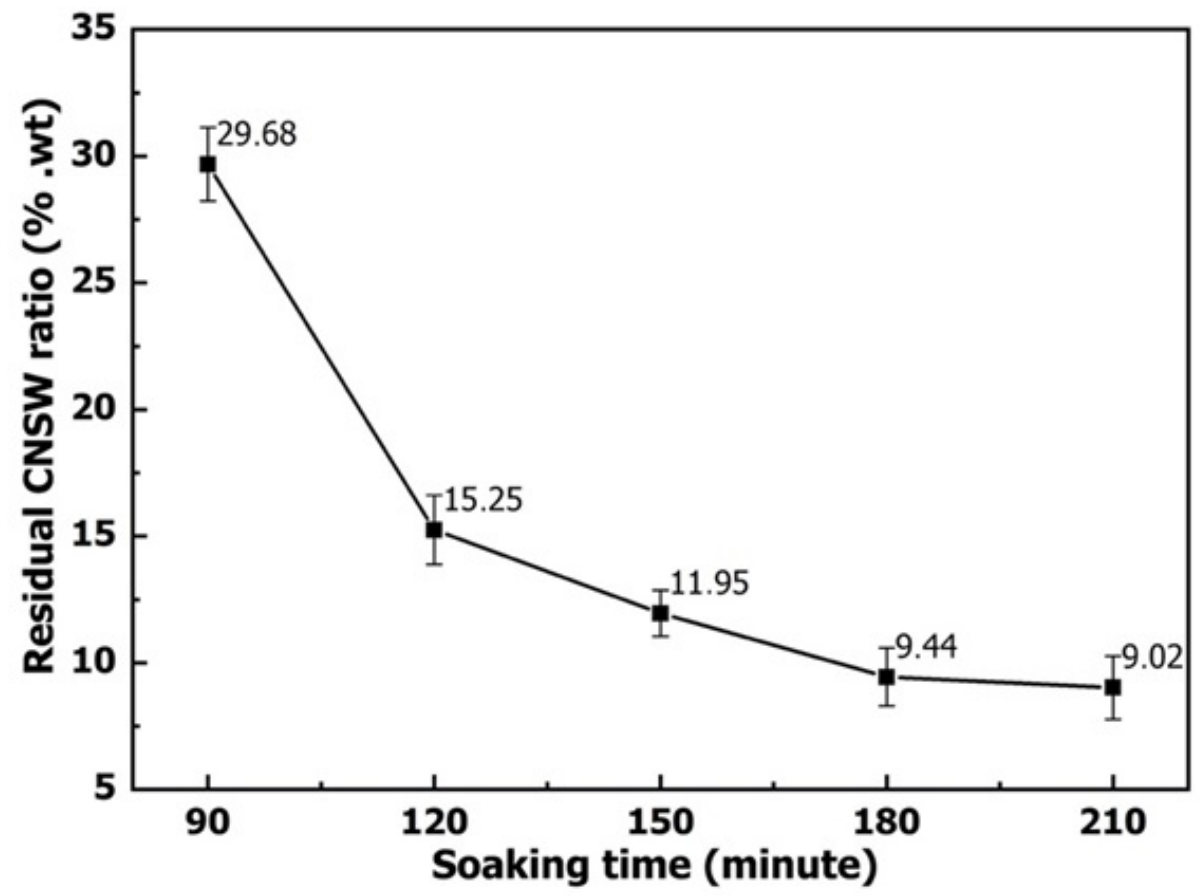

Figure 2: Effect of soaking time to residual CNSW ratio

Table 6: Gel permeation chromatography of wood liquefaction samples

\begin{tabular}{lllll}
\hline Sample & Soaking time (minutes) & Region & $\mathrm{M}_{n}$ & $\mathrm{M}_{w}$ \\
$\mathrm{ST}_{90}$ & 90 & 1 & 7056 & 10152 \\
& & 2 & 1325 & 1679 \\
$\mathrm{ST}_{120}$ & 120 & 1 & 7141 & 10845 \\
& & 2 & 1295 & 1610 \\
$\mathrm{ST}_{150}$ & 150 & 1 & 7410 & 10401 \\
& & 2 & 1282 & 1755 \\
$\mathrm{ST}_{180}$ & 180 & 1 & 7552 & 10640 \\
& & 2 & 1275 & 1545 \\
$\mathrm{ST}_{210}$ & 210 & 1 & 6997 & 10509 \\
& & 2 & 1323 & 1629 \\
\hline
\end{tabular}

had a similar structure and 180 minutes was the optimal time to fabricate wood liquefaction from CNSW at $150^{\circ} \mathrm{C}$.

\section{CONCLUSIONS}

In this study, the effect of soaking time at $150^{\circ} \mathrm{C}$ on the ability to prepared wood liquefaction was investigated. The FTIR results showed that there was LW formation in all samples at different soaking times. When increasing the soaking time, the residual CNSW ratio in resin decreased. However, when increasing the retention time of more than $180 \mathrm{~min}$ utes, the residual CNSW ratio did not decrease significantly. $\mathrm{M}_{w}$ and $\mathrm{M}_{n}$ values in the GPC results showed that the samples had coexistence of the polymer and oligomer and 180 minutes was the optimal time to fabricate wood liquefaction from CNSW at $150^{\circ} \mathrm{C}$. The ST180 sample had the residual CNSW ratio of 

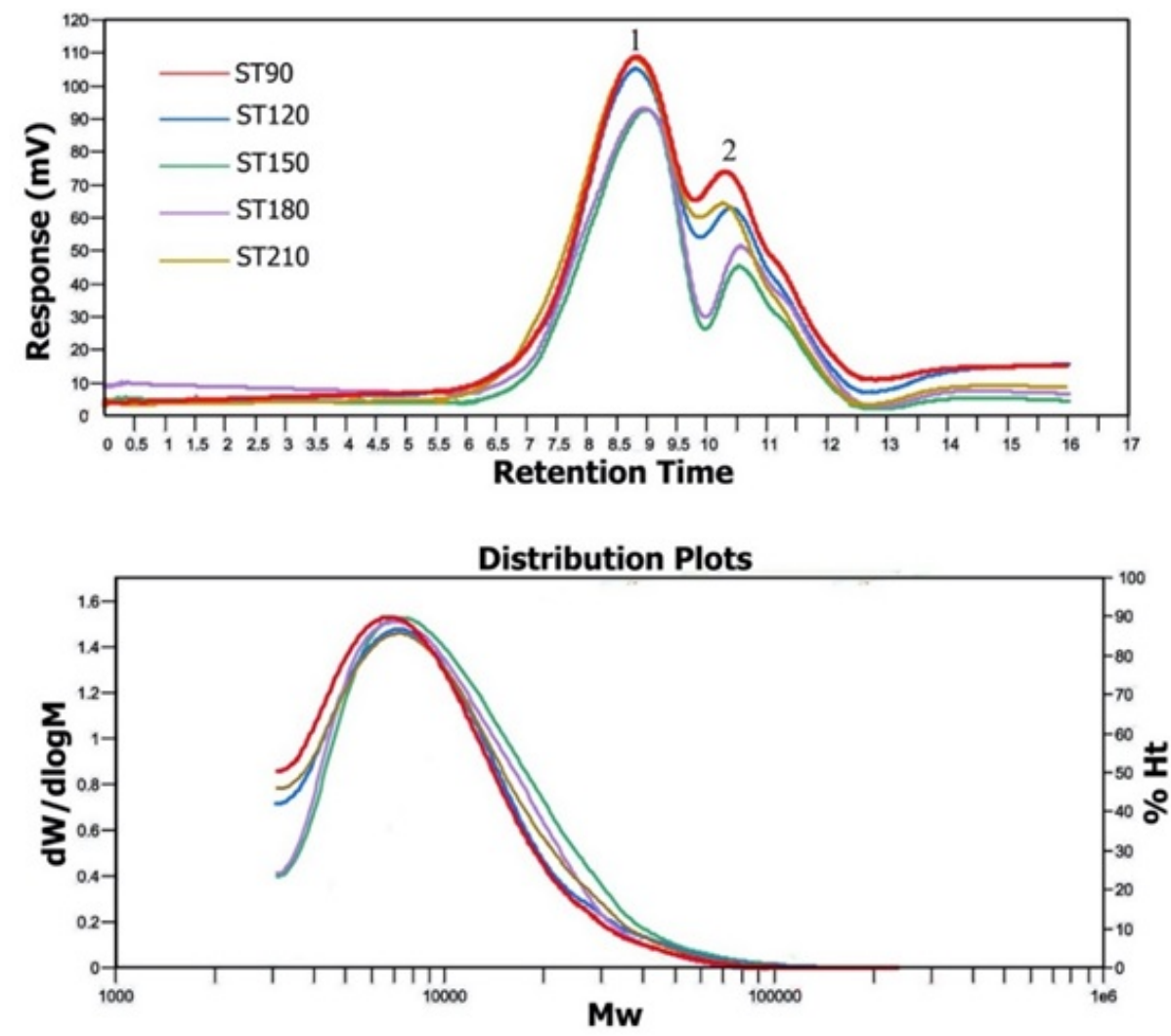

Figure 3: GPC result of wood liquefactionat $150^{\circ} \mathrm{C}$ for different soaking time

$9.44 \%$, the number average molecular weight $\left(\mathrm{M}_{n}\right)$ of 7552 , and the weight average molecular weight $\left(\mathrm{M}_{w}\right)$ of 10640 .

\section{ACKNOWLEDGEMENTS}

This research is funded by Vietnam National University Ho Chi Minh City (VNU-HCM) under grant number: C2019-20-27. We acknowledge the support of time and facilities from Ho Chi Minh City University of Technology (HCMUT), VNU-HCM for this study.

\section{CONFLICT OF INTEREST}

The authors declare that there is no conflict of interest regarding the publication of this article.

\section{AUTHOR'S CONTRIBUTION}

The authors confirm contribution to the paper as follows: study conception and design: Do Quang Minh, Kieu Do Trung Kien; data collection: Nguyen $\mathrm{Vu}$ Uyen Nhi; analysis and interpretation of results: Huynh Ngoc Minh; draft manuscript preparation:
Kieu Do Trung Kien. All authors reviewed the results and approved the final version of the manuscript.

\section{REFERENCES}

1. Jiang $\mathrm{H}$, et al. The pyrolysis mechanism of phenol formaldehyde resin, Polymer Degradation and Stability. 2012;97(8):1527-1533. Available from: https://doi.org/10. 1016/j.polymdegradstab.2012.04.016.

2. Huang $Y$, et al. Thermal and structure analysis on reaction mechanisms during the preparation of activated carbon fibers by $\mathrm{KOH}$ activation from liquefied wood-based fibers, Industrial Crops and Products. 2015;69:447-455. Available from: https://doi.org/10.1016/j.indcrop.2015.03.002.

3. Kobayashi $\mathrm{M}$, et al. Analysis on residue formation during wood liquefaction with polyhydric alcohol. Journal of Wood Science. 2004;50(5):407-414. Available from: https://doi.org/10.1007/ s10086-003-0596-9.

4. Seljak T, et al. Wood, liquefied in polyhydroxy alcohols as a fuel for gas turbines. Applied Energy. 2012;99:40-49. Available from: https://doi.org/10.1016/j.apenergy.2012.04.043.

5. Kurimoto $Y$. Wood species effects on the characteristics of liquefied wood and the properties of polyurethane films prepared from the liquefied wood. Biomass and Bioenergy. 2001;21(5):381-390. Available from: https://doi.org/10.1016/ S0961-9534(01)00041-1.

6. Jin Y. Liquefaction of lignin by polyethyleneglycol and glycerol. Bioresource Technology. 2011;102(3):3581-3583. PMID: 21050748. Available from: https://doi.org/10.1016/j.biortech 2010.10.050. 
7. Yamada $\mathrm{T}$, Ono $\mathrm{H}$. Characterization of the products resulting from ethylene glycol liquefaction of cellulose. Journal of Wood Science. 2001;47(6):458-464. Available from: https: //doi.org/10.1007/BF00767898.

8. Tohmura SI, et al. Preparation and characterization of wood polyalcohol-based isocyanate adhesives. Journal of Applied Polymer Science. 2005;98(2):791-795. Available from: https: //doi.org/10.1002/app.22072.

9. Ugovšek A, Sernek M. Characterisation of the curing of liquefied wood by rheometry. DEA and DSC, Wood Science and Technology. 2013;47(5):1099-1111. Available from: https:// doi.org/10.1007/s00226-013-0565-4.

10. Pan H. Wood Liquefaction in the Presence of Phenol with a Weak Acid Catalyst and Its Potential for Novolac Type Wood Adhesives. Doctor of Philosophy, Graduate Faculty of the Louisiana State, The School of Renewable Natural Resources Graduate Faculty of the Louisiana State. 2007;

11. Lin $L$, et al. Liquefaction of wood in the presence of phenol using phosphoric acid as a catalyst and the flow properties of the liquefied wood, Journal of Applied Polymer Science. 1994;52(11):1629-1636. Available from: https://doi.org/ 10.1002/app.1994.070521111.

12. Ahmadzadeh A, Zakaria S. Preparation of Novolak Resin by Liquefaction of Oil Palm Empty Fruit Bunches (EFB) and Characterization of EFB Residue. Polymer-Plastics Technology and Engineering. 2008;48(1):10-16. Available from: https://doi. org/10.1080/03602550802497776.

13. Lee WJ, Chen YC. Novolak PF resins prepared from phenol liquefied Cryptomeria japonica and used in manufacturing moldings, Bioresour Technol. 2008;99(15):7247-7254. PMID: 18243689. Available from: https://doi.org/10.1016/j.biortech. 2007.12.060.

14. Lee $\mathrm{SH}$, Teramoto $\mathrm{Y}$, Shiraishi N. Acid-catalyzed liquefaction of waste paper in the presence of phenol and its application to Novolak-type phenolic resin, Journal of Applied Polymer Sci- ence. 2002:83(7):1473 -1481.

15. Xie T, Chen F. Fast liquefaction of bagasse in ethylene carbonate and preparation of epoxy resin from the liquefied product. Applied Polymer Science. 2005;98(5):1961-1968. Available from: https://doi.org/10.1002/app.10039.

16. $\mathrm{Yu} F$, et al. Liquefaction of corn stover and preparation of polyester from the liquefied polyol. Appl Biochem Biotechnol. 2006;130(1-3):574-585. Available from: https://doi.org/ 10.1385/ABAB:130:1:574.

17. Kien KDT, et al. Study on Sintering Process of Woodceramics from The Cashew nut shell waste, Ceramic Processing Research. 2018;19(6):472-478.

18. Kien KDT, Minh DQ. Nghiên cứu chế tạo vật liệu gốm gỗ từ bã thải vỏ điều. Vietnam Journal of Chemistry. 2017;55(4E23):147-152.

19. Minh DQ, et al. The Influence of Composition of Raw Materials on Formation of Phenolic Resin from Cashew Nut Shel Waste (CNSW). Defect and Diffusion Forum. 2019;394(1):103108. Available from: https://doi.org/10.4028/www.scientific. net/DDF.394.103.

20. Kien KDT, et al. Ảnh hưởng của nhiệt độ đến khả năng tạo nhựa phenolic từ nguyên liệu bã thải vỏ điều, Vietnam Journal of Chemistry. 2019;57(6E1,2):403-407.

21. e EJ, et al. Cellulose liquefaction in acidified ethylene glycol. Cellulose. 2009;16(3):393-405. Available from: https://doi.org/ 10.1007/s10570-009-9288-y.

22. Alma MH, Basturk MA. Liquefaction of grapevine cane (Vitis vinisera L.) waste and its application to phenol-formaldehyde type adhesive. Industrial Crops and Products. 2006;24(2):171176. Available from: https://doi.org/10.1016/j.indcrop.2006.03. 010.

23. Naka K. Monomers, Oligomers, Polymers, and Macromolecules (Overiew). Encyclopedia of Polymeric Nanomaterials. 2014;p. 1-6. PMID: 25533776. Available from: https: //doi.org/10.1007/978-3-642-36199-9_237-1. 


\title{
Ảnh hưởng của thời gian lưu nhiệt đến khả năng tạo gỗ hoá nhựa từ nguồn nguyên liệu bã thải vỏ điều
}

\author{
Đỗ Quang Minh ${ }^{1,2}$, Huỳnh Ngọc Minh ${ }^{1,2}$, Nguyễn Vũ Uyên Nhi ${ }^{1,2}$, Kiều Đỗ Trung Kiên ${ }^{1,2, *}$
}

${ }^{1}$ Bộ môn Vật liẹu Silicat, Khoa Công nghệ Vật liệu, Trường Đại học Bách Khoa Thành phố Hồ Chí Minh (HCMUT), 268 Lý Thường Kiệt, quận 10, thành phố Hố Chí Minh, Việt Nam

${ }^{2} Đ a ̣ i$ học Quốc Gia Thành phố Hồ Chí Minh (ĐHQG-HCM), phuiơng Linh Trung, quận Thủ Đức, thành phố Hồ Chí Minh, Việt Nam.

Liên hệ

Kiều Đỗ Trung Kiên, Bộ môn Vật liệu Silicat, Khoa Công nghệ Vật liệu, Trường Đại học Bách Khoa Thành phố Hồ Chí Minh (HCMUT), 268 Lý Thường Kiệt, quận 10, thành phố Hồ Chí Minh, Việt Nam

Đại học Quốc Gia Thành phố Hồ Chí Minh (ĐHQG-HCM), phường Linh Trung, quận Thủ Đức, thành phố Hồ Chí Minh, Việt Nam.

Email: kieudotrungkien@hcmut.edu.vn

Lịch sử

- Ngày nhận: 25-11-2020

- Ngày chấp nhận: 16-03-2021

- Ngày đăng: 30-03-2021

DOI : 10.32508/stdjet.v4i1.796

Check for updates

\section{TÓM TẮT}

Gỗ hoá nhựa là một trong những sản phẩm nhựa phenolic. Tuy nhiên, không giống như các loại nhựa phenolic thương phẩm thường được tổng hợp từ phản ứng hoá học giưa phenol và formaldehyde, gỗ hoá nhựa thường được tổng hợp từ phản ứng giữa phenol với một loại nguyên liệu gốc gỗ và xúc tác tại nhiệt độ $120-180^{\circ} \mathrm{C}$. Tuỳ thuộc vào xúc tác sử dụng là bazơ hoặc axít, nhựa tạo thành có thể là nhựa nhiệt rắn hoặc nhiệt dẻo. Trong nghiên cứu này, gỗ hoá nhựa được tổng hợp từ bã thải vỏ điều, phenol và xúc tác axít sulphuric. Bã thải vỏ điều được lấy từ tỉnh Bình Phước Việt Nam và được nghiên đến kích thước hạt nhỏ hơn $500 \mu \mathrm{m}$. Phenol và xúc tác axít sulphuric sư dụng là các hoá chất thí nghiệm. Bột bã thải vỏ điều, phenol và axít sulphuric được trộn với nhau và được cho phản ứng ở $150^{\circ} \mathrm{C}$ trong những thời gian lưu nhiệt khác nhau. Thời gian lưu nhiệt thích hợp được xác định thông qua dư lượng bã thải vỏ điều còn lại sau phản ứng tạo nhựa. Ngoài ra, sản phẩm gỗ hoá nhựa cũng được các định số lượng phân tử số trung bình $\left(M_{n}\right)$ và phân tử khối trung bình $\left(\mathrm{M}_{w}\right)$ bằng phương pháp sắc ký thẩm thấu gel (GPC). Nhóm chức tạo thành được xác định bằng phổ biến đổi hồng ngoại (FTIR). Kết quả chỉ ra rằng nhựa tạo thành là nhựa nhiệt dẻo và thời gian lưu nhiệt thích hợp để tạo gỗ hoá nhựa là 180 phút. Mẫu nhựa này có dư lượng bã thải vỏ điều còn lại sau phản ứng là 9.44\%, phân tử số trung bình là 7552 , phân tử khối trung bình là 10640. Gỗ hóa nhựa từ bã thải vỏ điều có thể được sử dụng làm chất liên kết trong sản xuất tấm ván gỗ ép (MDF) hoặc làm nguyên liệu thúc đẩy quá trình kết khối trong sản xuất vật liệu gốm gỗ. Ngoài ra, gỗ hoá nhựa cũng có thể được nhiệt phân để tạo thành sợi cacbon. Sợi cacbon có thể được ứng dụng làm vật liệu gia cường trong sản xuất một số loại gốm.

Từ khoá: nhựa phenolic, gỗ hoá nhựa, bã thải vỏ điều
Trích dẫn bài báo này: Minh D Q, Minh H N, Nhi N V U, Kiên K D T. Ảnh hưởng của thời gian lưu nhiệt đến khả năng tạo gố hoá nhựa từ nguồn nguyên liệu bã thải vỏ điều. Sci. Tech. Dev. J. - Eng. Tech.; 4(1):714-721. 